\title{
ALGUNAS CONSIDERACIONES BÁSICAS SOBRE EL SISTEMA DE PRUEBA EN MATERIA PENAL
}

\author{
Carlos del Río Ferretti \\ Profesor de Derecho Procesal \\ Universidad Católica del Norte, Coquimbo.
}

I. Introducción. II. Antecedentes Históricos. III. Sistema de Libre Convicción. III.1. Objeto de la Prueba. III.2. Libertad de Prueba. III.3. Valoración. III.4. Módulo de Prueba.

\section{I.- Introducción}

En este trabajo lo que se pretende es buscar algunas pistas que nos permitan dar algunas explicaciones y afirmaciones sobre los fundamentos jurídicos del sistema de prueba de libre convicción en oposición al de prueba legal o tasada. Para ello se indagará desde el genuino aporte de diversas corrientes y posiciones doctrinales y de obras jurídico legislativas importantes.

Los cambios positivos de paradigma en el campo de la prueba ha sido siempre un ámbito fértil para el desarrollo teórico con una fuerte carga ideológica, tal vez ello se deba a la estrecha vinculación entre la justicia criminal y más precisamente con la concepción que se pueda tener, en un momento, de proceso penal con el devenir político e histórico jurídico de la cultura occidental.

Así, el interés de indagar en esta materia, estimamos, proviene principalmente del gran proceso de cambio en que se halla en este momento inmerso todo nuestro ordenamiento jurídico interno. Chile vive hoy una transformación profunda de parte importante de las estructuras orgánicas y funcionales del Derecho en general, a partir de un replanteamiento radical del ordenamiento jurídico que parece constituirse en un proceso, al fin, destinado a actualizar, en parte siquiera, nuestro orden jurídico que ha permanecido, en sus líneas generales, más o menos estático desde la época de la codificación.

Este proceso es especialmente importante en el área de la justicia criminal, específicamente, los cambios atingentes al proceso penal, que simbolizan claramente la nueva inspiración de nuestro legislador.

La legislación y, la codificación como manera propia de legislación, se inspiró en la concepción del racionalismo jurídico, pero con una importante herencia escolástica e inquisitiva de raigambre hispánica. Es así como en el siglo $X I X$ e inicios del $X X$, se estructuró el ordenamiento jurídico republicano que de forma evidente trasunta esta simbiosis particular, que conlleva una cierta incongruencia legislativa. Es clara la ma- 
nifestación de esta visión confusa del legislador, por ejemplo, tenemos de esta época las normas de la legislación civil contenidas en el Código del ramo, que en lo que respecta a importantes materias como las de hermenéutica contenidas en el título preliminar y las que consagran el estatuto de la propiedad en el libro II, son fruto del predominio del racionalismo y el liberalismo.

Por otra parte, en lo que se refiere a legislación procesal, particularmente la de naturaleza criminal, se revela un preponderante influjo, en toda la legislación republicana, del modelo inquisitivo y escolástico, herencia de la época colonial española. El sistema probatorio penal, en su integridad no escapa a esta influencia, por el contrario, suele ser uno de los puntos más sensibles de crítica desde diversas perspectivas de análisis.

El sistema probatorio que se consagra en nuestro Derecho es el de la prueba legal o tasada ${ }^{1}$, resabio del sistema inquisitivo hispanista, aunque con importantes morigeraciones.

En cambio en el futuro proceso penal, se consagra en término bastante amplios el sistema de libre convicción, cuestión que reviste gran importancia porque actualiza nuestra legislación en esta materia.

El tema de este trabajo se centra esencialmente en definir cuál es el objeto de análisis que nos ha de ocupar al hablar de sistema de pruebas de libre convicción en contraste con el de prueba legal y tasada, y en el transcurso de esa definición intentar señalar los puntos de relevancia que esto encierra para nuestro futuro sistema de justicia criminal.

Para dilucidar ese problema creemos fundamental hacer dos reflexiones preliminares. Una primera, en torno a qué se entiende por prueba y luego una segunda, referida a cuál es la finalidad de ésta.

Sobre el primer punto, se dice habitualmente que prueba es todo lo que sirve para dar certeza acerca de la verdad de una proposición ${ }^{2}$ o más preciso aún, la suma de

1 Es menester dejar en claro, como más adelante se establece, que nuestro sistema de prueba obedece al esquema de prueba legal negativo, es decir, se imponen ciertos criterios y limitaciones legales para la formación de la convicción y además se exige en el caso de la certeza condenatoria, la convicción moral.

Ahora bien, cuáles son los rasgos característicos del sistema de prueba legal que se conservan: podemos mencionar principalmente la reglamentación legal a que se somete los medios de prueba, por vía de ejemplo, las inhabilidades para ser testigo, la depreciación del testigo único y de la prueba indiciaria, y la importancia que aún mantiene la confesión, como medio de prueba.

No obstante lo dicho, se debe reconocer que el legislador ha ido paulatinamente consagrando otros sistemas de apreciación de prueba, distinto al legal, que significan una mayor libertad en la formación de la convicción del juez, especialmente el de la libre convicción o sana crítica. Asi tenemos el procedimiento laboral (sana critica), en materia penal, el delito de hurto (en conciencia) y ciertas leyes especiales como la de Seguridad del Estado (en conciencia), Ley de Tráfico de Estupefacientes (sana crítica), Legislación de Menores (en conciencia), Ley de Delitos Sexuales (sana crítica), Ley de Procedimiento ante Juzgado de Policía Local, entre otros.

2 CARRARA, Francisco, Programa de Derecho Criminal, tomo II. , Edit. Temis, Bogotá, Colombia, 1957, traducción Ortega Torres y Guerrero, p. 381. Esta definición tan clara como clásica nos la da CARRARA, pero 
motivos productores de certeza ${ }^{3}$. Por su parte probar, en tanto infinitivo denota la acción que engendra prueba, es decir, puede ser definido como comprobar, voz que a su vez, significa la verificación de la exactitud de ciertos hechos ${ }^{4}$.

Ahora bien, en un sentido jurídico, procesal y de finalidad en un sistema mínimamente acusatorio, ese comprobar será preferentemente de otro, porque a quien corresponde desarrollar principalmente esta labor es a las partes y su principal destinación es convencer al juez (sin embargo no opera absolutamente el aforismo probatio fit iudici, porque se comprende que también se dirige a las propias partes que así lo requieren para poder hacer valer sus derechos. Es una exigencia mínima para que exista verdadera contradictoriedad en el juicio penal).

Es así que, podríamos decir que probar es comprobar ${ }^{5}$ la verdad de un hecho, a otro, mediante su persuasión de certeza, obtenida con la prueba.

Como se ve, este intento por conceptuar lo que es la prueba y la acción de probar, entendida como comprobación de un hecho, nos remite inmediatamente al de verdad y sujeto cognoscente.

En efecto, lo anterior para que tenga sentido debe ser comprendido desde la perspectiva subjetiva, esto es, referida al sujeto cognoscente ${ }^{6}$. Frente a ella este sujeto puede encontrase en posiciones diversas, según sea su relación con la verdad. Estos estados son la certeza, probabilidad y la duda. Estados subjetivos distintos, suponen diversos resultados de la actividad de conocimiento desplegado por el sujeto.

Dicho esto último, de otro modo, la certeza expresa el juicio positivo acerca del resultado de la actividad cognoscitiva: quien tiene certeza está convencido de haber alcanzado la finalidad de la acción, es decir, de conocer. Esto es lo que denota la innegable naturaleza subjetiva del conocimiento y de su forma de expresión, cual es, la certeza?.

también la ocupan otros autores contemporáneos como CAFFERATA NORES, José, La prueba en el proceso penal, Edit. Depalma, 3ª Edic. Ampliada y actualizada(1.998), Buenos Aires, Argentina, 1.998, nota a pie de página $n^{2} 4$, p. 4.

3 MITTERMAIER, Carlos, La prueba en materia criminal, Edit Reus, Madrid, España, 1929, p. 72. También es tomada por CAFFERATA NORES, José, ibid cit.

4 Véase Diccionario de la Real Academia de la Lengua Española, Vigésimo primera edición, Madird, España, 1992, p. 371.

5 Véase CLIMENT DURÁN, Carlos, La prueba penal,Edit. Tírant Lo Blanch, Valencia, España, 1999, pp. 49 y s5, 58 y ss. Este autor realiza una clara diferenciación entre lo que es la prueba y la demostración propiamente tal. La primera tiene por objeto comprobar la verdad o falsedad de proposiciones fácticas, son los hechos los que se comprueban. En cambio la demostración tiene por objeto determinar la validez o no validez de una proposición abstracta o general, de determinada tesis u opinión, mas no de hechos. Sin embargo, agrega este autor, tanto la argumentación probatoria como la demostrativa son tomadas en cuenta por las partes y por el juez, para la formación de la convicción.

6 FRAmARINO DeI MALATESTA, Nicola, Lógica de las Pruebas en Materia Criminal, Edit. Temis, Colombia, Bogotá, 1.995, Tomo I, Cap. I y II.

7 Véase a FRAMARINO Y MAIER, Julio, op. cit, TOMO I, II y op. cit., p. 564, respectivamente. 
La probabilidad, en cambio, sólo significa un acercamiento plausible a la verdad que se pretende conocer. Por último, la duda no es más que el estado de neutralidad o, según Maier, de perplejidad frente a la verdad ${ }^{8}$.

Luego, para el desarrollo de esta labor el sujeto trabaja sobre (en ella recae la prueba) o con una hipótesis de verdad histórica o mejor dicho con ciertas afirmaciones de hechos con pretensiones de verdad histórica ${ }^{9}$, y aquí nos encontramos con el segundo punto: cuál es la finalidad del sistema de prueba, qué busca conocer mediante huellas, rastros o pruebas que se mantienen, que existen con relación al hecho hipotético que se indaga. En el caso de la hipótesis de una verdad histórica o mejor dicho con las afirmaciones que supuestamente la contienen, en el ámbito judicial, debemos recurrir al concepto de prueba, concebido como aquel sistema que importa el mecanismo idóneo que nos permite asir dentro del proceso un cierto conocimiento sobre hechos (negativos o positivos) con efectos jurídicos procesales válidos.

Sin embargo qué verdad se pretende descubrir. Algunos autores parecieran tratar de afirmar que se trata de la verdad material u objetiva o, como se ha dicho, la verdad verdadera, sobre todo en materia criminal. No obstante parece ser que el actual criterio dominante sería afirmar que la verdad material o como quiera que se le llame, es una meta inalcanzable, al menos mediante el proceso ${ }^{10}$.

Binder plantea las dificultades para alcanzar la verdad histórico material, en tres ideas básicas. Primero alude a los instrumentos de conocimiento de que se vale el proceso penal, ellos producirían habitualmente efectos distorsionadores. Si realidades físicas son distorsionadas por los instrumentos de conocimiento o medición de éstas, cuanto más sucederá con las realidades humanas. Luego, en segundo lugar alude a la construcción del relato que es ex post, que es histórico, y ello también produciría algún tipo de distorsión, porque se debe recurrir a registros de lo sucedido o porque el transcurso del tiempo borra o desdibuja las imágenes y recuerdos. $\mathrm{Y}$, en tercer lugar, porque la construcción del relato es obra del juez, trabajo que realiza desde el presente, desde una exigencia de solución apreciada como justa, dentro de un contexto y que incluye elementos subjetivos importantes referidos a la personalidad del sujeto tanto del presente como del pasado ${ }^{11}$.

Aparece lógico, en cambio, afirmar que si bien la verdad histórica objetiva o material no es susceptible de ser ganada con el proceso, no se debe sucumbir a la tenta-

8 Véase supra nota.

9 Cfr. CLIMENT DURÁN, Carlos, op. cit., pp. 70 y ss.

10 Véase ABALOS, Raúl, Derecho Procesal Penal,.., Edic. Jurídicas Cuyo, Argentina Mendoza, 1.993, p. 359 y ss. quien si bien es partidario de la verdad material, hace una sintesis breve pero acertada de los autores a favor de la verdad material y de los que están a favor de la verdad más limitada o más bien referida a la convicción del juez; KIELMANOVICH, Jorge, Teoria de la Prueba y Medios probatorios, Edit. Abeledo Perrot, Argentina, Buenos Aires, 1.996, p. 50

11 BINDER, Alberto, El relato del hecho y la regularidad del proceso: la función constructiva-destructiva de la prueba penal, Justicia Penal y Derecho, Edit. Ad-Hoc, Argentina, Buenos Aires, 1.993, pp. 22 y 23 
ción de una suerte de imperio de la verdad convencional o transaccional sin límites. Al contrario, se debe aspirar como mínimo, a la existencia de ciertos mecanismos que permitan objetivar una verdad formal o subjetiva ${ }^{12}$, a fin de legitimarla, de modo de que no campee sin límites la disponibilidad, manifestación del exclusivo y excluyente interés particular.

Ante este problema, que representa un evidente desafío a la razón, existen dos grandes formas conceptuales de enfrentarlo. Uno es el sistema de prueba legal o tasada y otro el sistema de libre convicción.

Cuando hablamos de sistema de prueba legal versus el de libre convicción, nos estamos refiriendo a que estos sistemas proponen maneras antagónicas de ordenar lo que se denomina la actividad probatoria. Sistema de prueba se puede definir en los siguientes términos: es aquél estatuto que regula la forma de indagación de los hechos dentro del proceso, que se manifiesta en la determinación de las formas y los medios por los cuales se puede arribar a una cierta verdad de los hechos; y en el modo de valorar esos medios ${ }^{13}$.

\section{Antecedentes históricos}

Los más antiguos antecedentes históricos del Derecho moderno occidental se hallan sin duda en el Derecho griego y, esencialmente, en el romano. Es evidente que en estas culturas jurídicas se encuentran las fuentes forenses más relevantes (sobre todo en el Derecho romano) que han inspirado y dado luz a las nuestras; el desarrollo jurídico positivo y doctrinal del Derecho Procesal no fue una excepción y dentro de él lo referido a las normas sobre la prueba, que si bien no presentan un desarrollo sistemáti$\mathrm{co}$, contienen valiosas normas, que sirvieron de sustrato a los ordenamientos occidentales.

En esta línea se puede afirmar que tanto en Grecia y Roma se idearon procedimientos bastantes acusatorios, fundados en los principios de la publicidad, oralidad e inmediatez y consecuentemente con ellos, imperó la libertad de apreciación de las pruebas por parte de los órganos jurisdiccionales, que en sus versiones más clásicas se organizaron como jurados. En Grecia, en su forma más tradicional y representativa se denominaron Dicasterios y en Roma Comicios Centuriados o Comicios de Tribus (suer-

12 En esta misma línea FAIRÉN GUILLÉN, Victor, Doctrina General del Derecho Procesal, Edit. Bosch, España, Barcelona, 1.990 , p. 422 y ss.

13 En este sentido se puede sostener que el objeto del sistema de prueba es la actividad probatoria, al menos en los términos que la define BINDER, Alberto, op. cit. p. 17. "La actividad probatoria en un sentido global es, en consecuencia, un conjunto de mecanismos y tareas que regulan el ingreso de información al proceso penal, desechan la información que se ha ingresado incorrectamente y, finalmente, construyen, con la información admitida, el supuesto de hecho, el relato de los hechos, los hechos o el supuesto fáctico -como se quiera llamarlo-, sobre el cual y para el cual se aplicará la solución prevista en el orden jurídico". 
te de asambleas populares) y los Tribunales por Jurados, Judices quaestiones perpetuae $e^{14}$

Sin embargo, con el advenimiento de la época imperial romana, se comienzan a conocer las primeras limitaciones probatorias que vienen a cercenar la libertad que poseían los órganos jurisdiccionales. Especialmente claro es este proceso en materia de prueba de testigos en que aparece con nitidez el aforismo de que un sólo testigo es ningún testigo: unus testis nullus testis, regla que también se halla consagrada en las Sagradas Escrituras ${ }^{15}$ y que pervivirá durante muchos siglos. En efecto, el propio Montesquieu sentenció "Las leyes que condenen a un hombre por la declaración de un sólo testigo, son funestas para la libertad"16. Aún más, hasta nuestros días, hay legislaciones que la contienen ${ }^{17}$.

Por otra parte estaban las normas de inhabilidad de testigos denominados improbi y de otras inhabilidades referidas a razones de parentesco o interés contenidas en el Digesto (Tomo II, Título V, 4,5,6, 9, 10, 13, 14, 15, 16, 17, 18, 19, 20, 21, 22, 24) ${ }^{18}$. ${ }^{19}$; y que las encontramos también en el Nuevo Testamento ${ }^{20}$.

14 Véase a MOMMSEN, Teodoro, Compendio del Derecho Público Romano, Edit. Jiménez Gil, Madrid, España, 1.999, p. 396 y ss.; FREDAS, Pietro, en Introducción a la Tercera Edición de las Pruebas Penales de Florián. reimpresión de tercera edición, Edit. Temis, 1.990, Colombia, Bogotá (Traducción Castellana Jorge Guerrero) , nota 21 a pie de página 31. Y WALTER, Gerhard, en Libre Apreciación de la Prueba, Edit. Temis, 1.985. Colombia Bogotá (Traducción Castellana de Tomás Banzhaf), p. 22. En el mismo sentido Mittermaier, en la "Prueba en Materia Criminal", Edit. Reus, Madrid. 1.929, p. 18.

15 Véase los siguientes pasajes bíblicos: Deuteronomio, cap. 19, v. 15-19; San Mateo, cap. 18, v. 16; San Juan, cap. 8, v. 13-18; Segunda Epistola Corintos, cap. 13, v. 1; Primera Epístola Timoteo, cap. 5, v. 19; Epistola Hebreos, cap. $10, v .28$.

16 MONTESQUiEU, Carlos, Del Espíritu de las Leyes", Tomo I, Edit. Albatros, Argentina, Buenos Aires, 1.942. p. 251.

17 Huelga decir que este principio es recogido en el vigente Código de Procedimiento Penal que en su artículo 459 señala que la declaración de dos testigos puede constituir plena prueba. En caso de existir un solo testigo esa declaración puede ser valorada como "presunción judicial" (artículo 464).

18 También en este punto propio de sistemas de prueba legal, recoge nuestro código de Procedimiento Penal (artículo 460) ciertas inhabilidades de testigos referidas a la falta de probidad o falta de imparcialidad, que consiste en un prejuicio realizado por el legislador sobre la credibilidad del testigo.

19 Véase Digesto, Versión Castellana de Alvaro D’ors y otros, Editorial Aranzadi, Pamplona, 1.972.

20 Con respecto a las inhabilidades para testificar que restan validez al testimonio, podemos decir que en las Sagradas Escrituras también hallamos un pasaje, precisamente, en el Nuevo testamento que se refiere claramente a ello (San Juan, cap. 8, v. 13-18) Es precisamente la Discusión sobre el Testimonio de Jesús sobre su origen divino, en que los fariseos le refutan señalándole que su testimonio no vale pues es testimonio de si mismo, a lo cual responde Jesús que si tiene valor su testimonio, pues no es de uno sino de dos, es de él y de quien lo ha enviado y agrega que en la ley de los fariseos se acepta el testimonio de dos.

Por otra parte recordemos que el vigente C.P.P., en su artículo $460 \mathrm{~N} N 11$, contiene la inhabilidad del denunciante que tiene interés en la causa y que presta testimonio en ella. Como se ve acá al igual que en pasaje bibli$\mathrm{co}$, se resta valor al testimonio de la misma parte vinculada con lo que se debate. Es la misma lógica normativa. 
Con respecto al imputado tenemos las normas sobre la tortura como medio de indagación que se permite desde el principado en adelante ${ }^{21}$.

No obstante, es la Edad Media, la época en que a propósito de la fusión de la cultura jurídica romana - influenciado por el Derecho germánico - y el Derecho canóni$\mathrm{co}$, se genera y sistematiza lo que denominamos sistema de prueba legal o tasada ${ }^{22}$. Ello coincide lógicamente con el proceso de instauración del sistema inquisitivo ${ }^{23}$. Lo cierto es que originalmente el Derecho canónico utilizaba la acusación privada como forma de excitación de la persecución criminal, no obstante el principio acusatorio se fue abandonando progresivamente hasta que a finales del siglo XII y principios del XIII, bajo el pontificado del Inocencio III, se consagró definitivamente el principio inquisitivo ${ }^{24}$.

Este sistema inquisitivo supuso la consagración definitiva del sistema de prueba legal, creación que tuvo su origen en la influencia del Derecho canónico, desde la perspectiva jurídica y de la escolástica desde el filosófico. El sistema inquisitivo nace inspirado en dos ideas primordiales. Por una parte, la necesidad de combatir aquí en la tierra, mediante el Derecho, el mal o la maldad humana y en segundo lugar, y consecuentemente con ello, pretende descubrir la verdad, siempre, respecto de todo hecho delictual, pues el delito representa el pecado social que incumbe a todos. $Y$ a la colectividad perseguir (oficialidad) y para ello se debe dotar al encargado de cumplir estas labores (juez inquisidor) de importantes poderes.

Sin duda que esta concepción nace de la trascendente influencia del Derecho romano, canónico y especialmente de la escolástica, que hace al sistema inquisitivo tender hacia la indagación de la verdad material ${ }^{25}$. Esto queda de manifiesto en los casi ilimitados poderes de investigación de los jueces inquisidores en los cuerpos legales más representativos de este sistema (La Constitutio Criminalis Carolina, Las Partidas o la Novísima Recopilación). Y también explica el lugar privilegiado que le cupo a la confesión bajo tortura como medio de prueba en este sistema ${ }^{26}$. A este medio se le denominó la reina de las pruebas, en cuanto aseguraba la posibilidad de investigar una serie de delitos que por su naturaleza constituían delitos de difícil indagación.

21 Véase a WALTER, Gerhard, op. cit., p. 24 y 25 ; y MITTERMAIER, Carlos, op. cit. p. 18 y ss.

22 Véase MITTERMAIER, Carlos, op. cit., p. 16 y ss.

23 Véase MAIER, Julio, op. cit., p.52 y ss. Este autor desarrolla en forma magistral este punto

24 Véase MITTERMAIER, Carlos, op. cit. p. 16 y ss., también a MAIER, J, op. cit. p. 52 y ss. y WALTER, Gerdhard, op. cit., p. 31. Este autor concluye al respecto: "Era ahora tarea del juez llevar de inmediato ante sus estrados cualquier acto punible del que llegara a tener conocimiento, procurarse todos los elementos necesarios para forjar su sentencia, practicar con precisión todos los elementos necesarios para forjar su sentencias. practicar con precisión todas las diligencias que fueren necesarias, sin esperar que actuasen las partes, buscar él mismo y llevar a cabo las pruebas para determinar la verdad de las circunstancias decisivas. En síntesis iniciaba su curso el proceso inquisitivo.

25 Véase MITTERMAIER, Carlos, op. cit. p. 16 y ss, y MAIER, Julio, op, cit. p. 64.

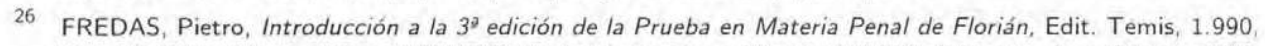
Bogotá , Colombia, p. 32 y ss.; WALTER, Gerhard, op. cit. p. 60 y ss.; MAIER, Julio, op. cit. p. 52 y ss.; PAILLAS, Enrique, Derecho Procesal Penal, Volumen I, Edit. Juridica, Chile, Santiago, 1.984, p. 38 y ss. 
Este es el fundamento que hallamos por ejemplo en las Sietes Partidas: "Cometen los omes a fazer grandes yerros, e malos, encubiertamente, de manera que non pueden ser sauidos, nin prouados. E porende tuuieron por bien los sabios antiguos, que fiziesen tormentar a los omes, porque pudiesen saber la verdad ende ellos" ${ }^{27}$.

Sin embargo, existía en este medio una suerte de contradicción dialéctica, porque si bien pretendía la búsqueda de la verdad, su propio mecanismo suponía la fórmula que se contrapone a la misma y que traduce en la negación de la libertad de decir lo que se quiere, pues lo que la tortura conseguía era arrancar una declaración que permitiera hacer cesar el dolor de los tormentos. Este procedimiento podía perfectamente conseguir una declaración de un débil inocente o a la inversa no obtener la declaración del hombre fuerte pero culpable.

Esto es fácil de comprender si se revisa, por ejemplo, lo que se consagraba en las Siete Partidas, sobre quiénes se hallaban sujeto y la forma de aplicar los tormentos. Se señala que se somete a tormento a aquél presunto delincuente que esté preso y que haya sido sorprendido infraganti o que existe en su contra prueba de un testigo y que además fuere hombre de mala fama o vil ${ }^{28}$.

Todos estos hombres podían ser objeto de tormentos ${ }^{29}$ y en cuyo caso debían declarar mientras se les aplicaban azotes o se le inferían heridas o se les colgaba de brazos y pies con cuerdas y se le cargaba la espalda y piernas con lóriga o con otra cosa pesada $^{30}$. Si llegaban a declarar el hecho delictual, concluía el tormento, pero era interrogado otra vez sin ser atormentado, para que refrendara lo dicho. Si no lo refrendaba, volvía a ser sometido a tormento. Según la naturaleza del delito podía ser atormentado dos, tres o más veces.

Ante tal crueldad estimamos muy posible lo ya dicho, en el sentido de que efectivamente se produjera la auto incriminación del inocente $e^{31}$.

Es decir, y sin embargo, todo lo de la supuesta búsqueda de la verdad material a través de las facultades de indagación que se le conceden al juzgador, contiene una suerte de contradicción dialéctica, que consiste en que si bien, se le otorgan al juez, poderes, ello se viene abajo mediante la imposición del sistema de valoración tasada rigurosamente formalista del que no se puede apartar llegado el momento de senten-

27 Véase Código de Las Siete Partidas, Partida 7?2. Título XXX. Edit. Imprenta de la Publicidad, España, Madrid, 1.848 .

28 Véase Código de las Siete Partidas, Partida $7^{2}$. Titulo XXX.

29 En efecto, todos estos hombres podían ser sometidos a tormento, salvo algunas excepciones previstas en el Partida $7^{\text {a }}$, Libro II que exime a los menores de 14 años, ni a caballero, ni maestro de leyes u otro oficio, ni a consejeros, ni a mujeres embarazadas. Véase Código de Siete Partidas.

30 Esto es lo que dice textualmente la Partida $7^{2}$, Título XXX, Ley II.

31 Sin duda también se puede presentar la situación inversa de que el delincuente soporte el tormento, y no confiese, quedando absuelto, ya que esta prueba estaba revestida de un alto grado de credibilidad. 
ciar. Esto, no obstante, opera como el único modo posible de limitar sus notables poderes $^{32}$.

En resumen lo que sucede es que el legislador, en el momento cúlmine de la labor jurisdiccional, sustituye al juez en la apreciación del mérito del proceso, se impone una valoración anticipada y abstracta del legislador ${ }^{33}$. Se podría afirmar que en realidad no se valoran casos sino más bien se valoran hipótesis ${ }^{34}$.

En definitiva el contrasentido consiste en que el sistema inquisitivo y de la prueba legal nace para la búsqueda de la verdad material y se tiene que terminar por conformar con una verdad formalista e hipotética.

No obstante y tal vez por la razón indicada es que la doctrina ideó un sistema de prueba legal que cumpliera con el objetivo de servir de límite a los importantes poderes del juez y a su vez impidiera las eventuales injusticias, a que pudiera llevar el sistema legal en su versión más extrema (positivo). A este sistema se le denominó prueba legal negativa. Consiste en que la ley si bien impone los medios de prueba por los cuales se pueden probar los hechos en el proceso y su peso, exige además la convicción personal para poder condenar ${ }^{35}$. De este modo se impide que producto del excesivo formalismo apriorístico y abstracto del sistema legal positivo llegue incluso afectar el principio de inocencia a través de una condenación injusta.

Esta teoría tuvo sus principales partidarios en Filangieri, Romanogsi y el propio Carmignani ${ }^{36}$ y sus primeras consagraciones legislativas están presentes en la Ordenanza de Procedimiento Penal Austríaca de 1803 y en el Código de procedimiento Penal de la República Cisalpina. Huelga decir que también nuestro vigente C.P.P. es un ejempln

32 Con respecto a esta afirmación encontramos innumerables autores de notable valía que sostienen lo mismo. Entre los más destacados, están, BECCARIA. César, De Los Delitos y De las Penas, p. 116 y 117. Edit. Ejea, Argentina, Buenos Aires, 1.958 (Traducido por Santiago Sentis Melendo); BENTHAM, Jeremías, Tratados de las Pruebas Judiciales, Edit. Ejea, Argentina, Buenos Aires, 1.959 (Traducido por manuel Ossorio), p. 12 y ss; MITTERMAIER, Carlos, op. cit., p. 21 y ss., FRAMARINO DEI MALATESTA, Nicola, Lógica de las Pruebas en Materia Criminal, Edit. Temis, Colombia, Bogotá, 1.995 (Traducción de Jorge Guerrero), p. 108 y ss; FLORIÁN, Eugenio, De las Pruebas Penales, Edit. Temis, Colombia, Bogotá, 1.990 (Traducido por Jorge Guerrero), p. 358 y ss; MAIER, Julio, op, cit. p. 52 y ss, en relación a p. 569 y ss.

33 Hay que reconocer eso sí, que las reglas de valoración de la prueba, suelen ser el decantamiento de la sabiduria jurídica acumulada a lo largo de la historia. El ejemplo más clásico es el referido a las normas sobre testigos que se remontan al Derecho romano e incluso a las sagradas escrituras. El problema es que esa valoración es apriorística, despreciando así la particularidad de cada caso. En realidad no se valoran casos sino más bien se valoran hipótesis.

Esta afirmación es compartida por casi toda la doctrina europea. Furno, por ejemplo, desarrolla la línea argumental de la apreciación abstracta, aprioristica e hipotética con gran maestría en su obra Teoría de la Prueba Legal, p. 25 y ss., Edit. Revista de Derecho Privado, España, Madrid, 1.954.

Véase a BOFILL, Jorge, La prueba en el Proceso Penal (apuntes sin editar y sin fecha). Entre los clásicos que tratan el tema están MITTERMAIER, Carlos, op. cit. p. 77 y ss. y FLORIÁN, Eugenio, op. cit. p. 361 y ss

Véase MITTERMAIER, Carlos, op. cit. p. 77 y FLORIÁN, Eugenio, op. cit. 361 y BOFILL, Jorge, op. cit. 
típico de ésta, según se desprende del tratamiento que hace de los medios de prueba y especialmente la consagración del artículo 456 bis $^{37}$.

Según lo que hemos dicho, podemos afirmar que el sistema de la teoría legal o tasada pervivirá, desde su generación, durante todo lo que resta de edad media en su versión positiva y con posterioridad en su versión negativa, más acorde con las nuevas concepciones políticas y jurídicas que surgen a partir del siglo XVIII.

Sin embargo con el advenimiento de la época moderna y más precisamente con el movimiento revolucionario Francés, se comienza a cuestionar fuertemente la forma de hacer justicia en materia criminal.

En efecto, desde esta época en adelante, se comienza a luchar por un sistema que se adecuara mejor al nuevo modelo político que se pretendía imponer ${ }^{38}$. Un sistema cuyo sustento son las ideas de la igualdad, la libertad política y el reconocimiento de ciertos derechos individuales, lo que se traduce en la concepción del nuevo régimen político republicano. Esto último suponía una nueva forma de hacer justicia conforme al principio de soberanía popular también manifestada en la función jurisdiccional. El mecanismo para ello será concebir un juicio criminal donde prime la publicidad, la oralidad, también en un principio la participación ciudadana en la administración de justicia (se conciben algunas formas de jurado, pero luego se impone en Europa continental la idea de jueces profesionales) y consecuentemente la libertad de convencimiento ${ }^{39}$.

Sobre el sistema de libertad probatoria, debemos decir que compartimos lo expuesto por diversos connotados autores ${ }^{40}$, en el sentido que no se entendió siempre como lo concebimos ahora. Inicialmente, sin duda por el fuerte influjo del ejemplo anglosajón y tal vez del romano clásico, se trató de idear un sistema de íntịma convicción más propio de un jurado, en tanto el juzgador no se hallaba en la necesidad de motivar su decisión ${ }^{41}$; se concebía en realidad como un acto de conciencia interna o de pura voluntad y como tal, imposible de justificar. En esta línea resulta especialmente claro lo

37 En coincidencia con BOFILL (véase nota supra) estimamos que nuestro vigente C.P.P. obedece a la teoría de la prueba legal negativa, sobre la base del tratamiento que el Código hace de los medios de prueba, las limitaciones probatorias, las reglas de valoración que establece y su vinculación con el artículo 456 bis del C.P.P.

38 Cfr. BOFILL, Jorge, op cit.

39 Véase A FREDAS, Pietro, op. cit. p. 31; MAIER, Julio, op. cit., Tomo 1b,p. 213 y ss.

40 Véase a MONTERO AROCA, Juan, Principios del Proceso Penal,Edit Tirant Lo Blanch, España, Valencia, 1.997, p. 161 y ss; WALTER, Gerhard, op. cit., p. 75 y ss; ASENCIO MELLADO, José María, La prueba. Garantias Constitucionales derivadas del artículo 24.2; en Materiales de lectura para Seminario de dos días, sin fecha; BOFILL. Jorge, op. cit.

${ }^{41}$ Sin embargo en la actualidad aún en los sistemas de jurados se impone la obligación de motivar adecuadamente las decisiones que adoptan. En España, por ejemplo, con la dictación de la ley 81.995 de 1995 sobre jurados, se obliga al jurado, según lo dispone el artículo 52, a realizar una secuenciación lógica de los hechos sobre los cuales se pronuncia como probados y el artículo 61 que se refiere al acta de votación, obliga a realizar una exposición de motivos de sus argumentos. Explicar qué da por probado, qué no da por probado y mediante cuáles elementos de prueba. Véase Exposición de Motivos de la Ley de Jurados, 81.995 de 1995; DÍAZ CABALE, José, Prueba, Deliberación, Veredicto y Sentencia, en Cometarios Sistemático a la ley de Jurados, VV. AA., Edit Comares, 1996, p. 328 y ss. 
que dispuso el Decreto de 1791 que crea el jurado en Francia, que instaba a estos en los siguientes términos: "la ley no pide cuenta de los medios por los cuales (los jurados) se han formado una convicción; no les prescribe las reglas a las cuales deben atribuir en particular la plenitud y la suficiencia de una prueba; ella les exige que se interroguen a sí mismo en silencio y en recogimiento y que busquen determinar, en la sinceridad de su conciencia, qué impresión han causado en su razonamiento las pruebas aportadas contra el acusado y los medios de defensa. La ley no les dice: "tendreis por verdad todo hecho atestiguado por tal número de testigos, o no considerareís suficientemente establecida ninguna prueba que no haya sido formada por tantos testigos o por tantos indicios"; la ley hace una sola pregunta, que compendia toda la medida de su deber: ¿tenéis una convicción íntima?"

Luego esta misma norma pasará al artículo 342 del Código de Instrucción Criminal de 1808 (actualmente se halla casi exactamente igual en el artículo 353 del Código de Procedimiento Penal Francés).

Este sistema como bien hemos dicho no suponía una motivación del fallo, sino más bien se apoyaba en la idea de la impresión total que se forma el jurado a partir de lo debatido en el juicio oral.

Esta concepción tuvo sus influencias en Europa continental, especialmente en Alemania y España. En la primera se debatió fuertemente el tema siempre ligado a la necesidad de crear tribunales compuestos por jurado, lo que se produjo a mediados del siglo XIX.

En España, también se tomó el modelo del jurado y de la íntima convicción (entendida a la manera francesa), pero el jurado duró poco tiempo, permaneciendo, eso sí, y curiosamente, la idea de íntima convicción con prescindencia de fundamentar la sentencia ${ }^{42}$, situación que se perpetúa durante mucho tiempo, llegando incluso hasta finales de la década del 70 del presente siglo. De esta época es famosa una sentencia del año 1978, que establece lo siguiente: "el juzgador, a la hora de apreciar las pruebas practicadas, las alegaciones de las partes y las declaraciones o manifestaciones del acusado, lo hará no ya sin reminiscencia de valoración tasada o predeterminada por la ley, o siguiendo las reglas de la sana crítica, o de manera simplemente lógica o racional, sino de un modo tan libérrimo y omnímodo que no tiene más freno a su soberana facultad valorativa que el proceder al análisis y a la consecutiva ponderación, con arreglo a su propia conciencia, a los dictados de su razón analítica y a una intención que se presume siempre recta e imparcial"43.

Este estado de cosas solo concluye a principios de los 80 , con un fallo del Tribunal Constitucional que sostiene la necesidad de motivar las sentencias. Este fallo pro-

\footnotetext{
42 Véase ASENCIO MELLADO, José Maria, op. cit

43 Sentencia del TS del 10 de febrero de 1.978, citada por ORTELLS RAMOS. Manuel, Derecho Jurisdiccional,

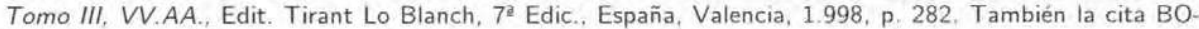
FILL, Jorge, op. cit.
} 
pone lo siguiente: "El principio de libre valoración de la prueba, recogido en el artículo $741 \mathrm{LECr}$, supone que los distintos elementos de prueba pueden ser libremente ponderados por el Tribunal de instancia, a quien corresponde, en consecuencia, valorar su significado y trascendencia en orden a la fundamentación del fallo contenida en la sentencia. Pero para que dicha ponderación pueda llevar a desvirtuar la presunción de inocencia, es precisa una mínima actividad probatoria producida con las garantías procesales que de alguna forma pueda entenderse de cargo y de la que se pueda deducir, por tanto, la culpabilidad del procesado, y es el TC el que ha de estimar la existencia de dicho presupuesto en caso de recurso. Por otra parte, las pruebas a las que se refiere el propio artículo 741 LECr "son las pruebas practicadas en el juicio". Luego, el Tribunal penal sólo queda vinculado a lo alegado y probado dentro de él (secundum allegata et probata)" ${ }^{\prime 4}$.

En cuanto a la influencia de la íntima convicción en Chile, seguimos lo expuesto por el Profesor Paillas ${ }^{45}$, el que constata la existencia de la penetración de esas ideas en la segunda mitad del siglo XIX, pero al parecer por razones ajenas a las que dieron origen al sistema. En efecto, en el año 1876, durante el mes de agosto, se dicta una ley al respecto, que dispone que para los procesos por delitos de homicidio, hurto, robo, incendio y accidentes de ferrocarriles, el tribunal apreciará la prueba con entera libertad.

La motivación de esta norma habría sido facilitar la penalización de estos delitos que en el anterior sistema por razones de la estructuración de la prueba en plena y semiplena, quedaban sin sanción. Recordemos que generalmente la prueba plena estaba apoyada en la confesión que ya no se podía obtener mediante tormentos y que por tanto perdía parte importante de su eficacia y ello era especialmente grave pues la prueba semiplena no permitía, por sí sola, fundar una sentencia condenatoria.

Sin embargo la primera norma que se refiere directamente a que los tribunales han de fallar apreciando prueba en conciencia es la ley que alude a los procesos seguidos por falsificación, adulteración o uso fraudulento de una marca industrial registrada, dictada el 24 de Octubre de $1898^{46}$.

\section{El sistema de libre convicción}

Para poder discernir el modo como se ha configurado este sistema, nos referiremos a qué elementos o criterios comprende y cuál es el contenido de cada uno de ellos, pues éstos son justamente su nota distintiva.

En efecto, el sistema de libre convicción, entendido modernamente, supone la coexistencia de ciertos criterios que permiten asegurar, al mismo tiempo, libertad, ga-

\footnotetext{
44 Citado por BOFILL, Jorge, op. cit.

45 Véase PAILLAS, Enrique, op. cit. p. 65 y ss.

46 Véase Ibidem, p. 67
} 
rantía y racionalidad en la actividad de incorporación, acreditación de hechos y valoración de la prueba.

Lo anterior se puede plantear ontológicamente y desde la perspectiva de la actividad probatoria, del siguiente modo: la incorporación de los hechos y la información que corresponde al objeto de prueba o thema decidendum; la adquisición de la información que tiene que ver con la libertad de prueba; y la estructuración del relato que se vincula con la valoración de la prueba ${ }^{47}$.

III.1. Objeto de la prueba. Es así, que tenemos en lo que se refiere a la determinación del objeto de prueba (determinación de los hechos objeto del pleito o thema decidendum), aunque en estricto rigor no se halle comprendido necesariamente dentro del sistema de libre convicción, el principio de la aportación de parte que parece ser su natural inspirador ${ }^{48}$, reconociendo, eso sí, como natural contrapeso la existencia de ciertos criterios de objetivación, en especial atención al interés colectivo que implica el proceso penal.

Ello viene a ser la forma de vigencia que adopta el principio inquisitivo como investigación oficial de la verdad de los hechos. Esta es la posición de los profesores Maier, Walter, Bofill ${ }^{49}$, entre otros y con algunos matices ${ }^{50}$.

Dicho de otro modo, corresponde a las partes la introducción de los hechos y sobre ellas también debe recaer la carga de probar o mejor dicho la función de probar ${ }^{51}$, pues se parte del supuesto que ello se da dentro de la idea del sistema y principio acusatorio. No obstante, justificados por el claro interés colectivo que siempre implica un juicio criminal y de algún modo por la existencia, aún, dentro de los sistemas acusatorios formales, del principio inquisitivo de la investigación oficial de la verdad, se plantea la existencia y necesidad de ciertos mecanismos de objetivación de la actividad subjetiva.

Lo anterior cobra un importante significado para el futuro sistema chileno, pues el Proyecto de Código Procesal Penal, contempla a nuestro juicio, varios mecanismos que podríamos denominar de objetivación de la verdad (reconocemos eso sí que la regla

47 Véase BINDER, Alberto, op. cit.

48 Véase CLIMENT DURÁN, Carlos, op, cit., pp. 41 y ss.

49 Véase MAIER, Julio, op. cit. p. 580 y ss., WALTER, Gerherd, op. cit. 315 y ss., BOFILL, Jorge, op cit.

50 Véase MAIER, Julio, op. cit. Tomo l-b, p. 564 y ss.

51 Esto de que la carga de probar corresponde a las partes, no se puede entender en su sentido ordinario y civilista, porque en estricto rigor no existe de esa forma, fundamentalemente en razón de que en materia penal el que debe probar es la parte que sustenta la acusación y esta parte, representada por el Ministerio Público, no es una parte con intéres parcial análoga al de un simple particular, por el contrario, el interés que representa es el interés colectivo, social, estatal, de actuar correctamente la ley panal y de esa forma contribuir a la vigencia del Estado de Derecho. Cuando ocupamos el giro la carga de probar corresponde a las partes, nos referimos a la función quer cumplen las partes en la incorporación de la prueba al juicio penal, función en la cual le cabe un rol secundario al juez. Véase en este snetido la nota $n^{\circ} 76$. pp. 20 y 21. 
general es que son las partes las que tienen la iniciativa en la búsqueda de la verdad y su prueba, de modo que podríamos hablar de una cierta verdad subjetiva objetivable).

Los mecanismos de objetivación que observamos en la futura legislación son los siguientes: la prueba anticipada, la potestad del tribunal de ordenar pruebas en la misma audiencia, la potestad del juez de garantía de ordenar ciertas diligencias de investigación una vez agotada ésta por el fiscal, la facultad de las partes de incorporar algunas actuaciones de la instrucción mediante la contrastación de éstas con las declaraciones que presten los testigos y peritos en la audiencia, la potestad del tribunal de dirigir preguntas a los testigos y peritos.

III.2. Libertad de prueba, de investigación y apreciación, y prueba ilícita. En cuanto a la libertad de medios debemos indicar que si bien este sistema supone libertad de medios de prueba para acreditar los hechos y libertad para su valoración, también reconoce, la necesidad de imponer criterios de limitación con fin de garantía ${ }^{52}$. Ello tiene que ver esencialmente con el debido proceso y los derechos fundamentales de los intervinientes y de terceros en el proceso ${ }^{53}$.

Binder en este punto es bastante exigente y garantista pues afirma que el principio de la libertad de medios de prueba y la búsqueda de la verdad histórica debe ceder ante el verdadero principio esencial y básico que es el de la limitación de los medios de prueba o como él dice a las adquisiciones de la información, en homenaje al concepto de dignidad de la persona y sus derechos fundamentales ${ }^{54}$

Incluso en eso se afirma, este autor, para sentenciar que en todo sistema moderno debiera haber prueba legal, pero en un sentido diverso al del sistema inquisitivo, más bien negativo y de garantía en la finalidad de impedir la formación de la convicción con ciertos elementos que violen ciertas normas o principios protectores ${ }^{55}$. La legalidad de la prueba, desde esta óptica tiene más bien por fin dar un marco ético-jurídico a la libertad de prueba ${ }^{56}$.

52 Véase Ibídem, p. 462 y ss. Este autor propone claramente que las llamadas, por él "prohibiciones probatorias", son una limitación libre indagación de los hechos.

Véase BOFILL, Jorge, op cit.

54

BINDER, Alberto, op. cit. p. 25 y ss. Incluso en eso se afirma para sentenciar que en todo sistema debiera haber algo de prueba legal pero en un sentido negativo y de garantía. También es por esa razón que él ha identificado tres niveles de protección y limitación dentro del proceso penal. Un primer nivel es el que se refiere a la prohibición absoluta de ciertos métodos y materias, como son la tortura, la coacción y la amenaza. El segundo nivel está representado por aquellas que requieren una estricta observancia y autorización judicial, como son las que afectan los derechos a la libertad, privacidad y la intimidad. $Y$ el tercer nivel de protección denominado de la legalidad de la prueba, que dice relación con la prohibición de incorporación formal de la información, si no es mediante los canales y procedimientos ajustados a derecho, de modo que se excluyen por ejemplo, información proveniente de rumores, testimonios anónimos o secretos y los conocimientos privados del juez. Ibid. También reitera estas ideas en su obra Introducción al Derecho Procesal Penal,p. 174 y ss. Edit. Ad-Hoc, , $1^{2}$ edic., 1.993, Buenos Aires, Argentina.

56 CAFFERATA NORES, José, op, cit. p. 16 (nota a pie de página, $N^{\circ} 23$ ) 
En cuanto al desarrollo del concepto de prueba ilícita: En doctrina emerge con fuerza en los últimos años, como muy bien explica Carocca ${ }^{57}$, sin embargo estimamos que podemos hallar ideas de este concepto entendido modernamente en algunos otros autores bastante clásicos, por ejemplo. Florián que en su más importante obra en materia de prueba entrega una idea aunque básica, bastante clara de lo que se trata: "Esta libertad de los medios de prueba encuentra naturalmente, dos limitaciones jurídicas dignas de notar, una de ellas sustancial y la otra formal; la primera en el sentido de que el medio de prueba utilizado no esté prohibido por la ley; la segunda en el sentido de que el medio de prueba no puede utilizarse sino en cuanto se ha aportado con todas las formalidades al acervo procesal, pero esta última limitación se refiere más especialmente al procedimiento probatorio.

Con todo y ser así, antes que en la ley jurídica de la libertad de los medios de prueba encuentra un límite en la ley moral y en la conciencia pública, razón por la cual no pueden aceptarse medios de prueba inmorales $u$ obtenidos con procederes violentos (amenazas, golpes, etc)" ${ }^{\prime 58}$.

Como se ve, en el primer párrafo de la cita, se alude más a un concepto de prueba ilegal o irregular, en el concepto de Carocca ${ }^{59}$, es decir, entendida como aquella que es contraria o está prohibida por la ley o que no respeta ciertas formalidades procesales de aportación, sin aludir a los derechos fundamentales.

No obstante en el segundo párrafo que se cita, ya existe una idea clara que alude a un concepto de dignidad y de respeto a la persona (y por lógica deducción, de sus derechos fundamentales) y del rechazo de los medios de prueba que las vulnere; nota distintiva de lo que se entiende por prueba ilícita.

Luego, la idea de prueba ilícita supone necesariamente la tarea de determinar qué derechos fundamentales se hallan protegidos. Creemos acertado señalar y concordando con la doctrina más moderna en la materia ${ }^{60}$, que la respuesta está en el orden constitucional que a partir de la postguerra se preocupa preferentemente de dar protección y vigencia real a este tipo de garantías procesales ${ }^{61}{ }^{62}$ y en el caso chileno, por su

57 Véase CAROCCA, Alex, Una Primera Aproximación al Tema de la Prueba llícita en Chile, Revista lus et Praxis, año $1, n^{2} 2,1.998, p p .301-322$. En este trabajo el autor afirma que la prueba ilícita como concepto está el referido a la vigencia y respeto de los derechos fundamentales consagrados principalmente en el texto constitucional, diferenciándolo con otros semejantes.

58 FLORIÁN, Eugenio, op. cit. pp. 224 y 225. Este autor desarrolla además este tema refiriéndose a casos concretos sobre ciertas hipótesis de prueba ilicita por violar derechos esenciales como la integridad personal, como el caso del narcoanálisis, hipnosis o el detector de mentiras (las negritas de la cita del texto es propia).

59

Véase CAROCCA, Alex, op. cit. p. 309

60 Véase Ibidem, p. 301 y ss. Este autor es el que propone esta teoría en Chile.

61 Véase KIELMANOVICH, Jorge, op. cit. p. 56

62 En 1.958 en el IV Congreso de Derecho Comparado que se celebra en Bruselas, se adoptó el siguiente acuerdo: "Todos los procedimientos de investigación que constituyan un atentado contra la personalidad humana, como el narcoanálisis, deben excluirse de entre los medios de instrucción judicial", citado por FLORIÁN, Eugenio, op. cit. p. 235 
intermedio se recoge además la protección contenida en los tratados internacionales sobre derechos humanos. En concreto Carocca menciona a modo ejemplo, los siguientes derechos: derecho a la vida pública y privada y a la honra de las personas (art. 19 № 4 inc.1 C.P.R.); a la inviolabilidad del hogar y de toda forma de comunicación privada (art. 19 № 5 C.P.R.); a la libertad de conciencia (art. 19 № 6 C.P.R.); a la vida y a la integridad física y psíquica de las personas (art. 19 № 1 C.P.R.); a la libertad personal e individual (art. 19 № 7 C.P.R.) ${ }^{63}$

Este tema tiene una especial importancia para el nuevo proceso penal chileno, pues si bien se prevé la regla general de la libertad de medios, según se explicita en el artículo 199 inc. $1^{\circ}$, que dispone expresamente "Libertad de prueba. Todos los hechos y circunstancias pertinentes para la adecuada solución del caso sometido a enjuiciamiento podrán ser probados por cualquier medio producido e incorporado en conformidad a la ley, salvo disposición legal expresa en contrario" ${ }^{\prime 4}$. A su turno, y por primera vez, se consagran normas que recogen ciertas hipótesis de prueba ilícita.

En efecto, el artículo 122 del Proyecto de Código Procesal Penal trata sobre el interrogatorio del imputado (y que también es aplicable a los testigos por remisión del artículo 216) que cautela porque se respete la libertad de la declaración, proscribiendo métodos que la impidan como las preguntas capciosas o sugestivas o ciertas promesas o que menoscaben la integridad física y psíquica del declarante como coacción, amenaza o violencia corporal o psíquica y administración de psicofármacos e hipnosis ${ }^{65}$.

También existen otras normas sobre prueba ilícita más genéricas y que por tanto permitirían dar protección a los derechos fundamentales en otras hipótesis de ilicitud, distintas de las contempladas en el artículo 122. En este sentido cobra especial importancia la disposición del artículo 193 del proyecto de Código Procesal Penal que contiene una presunción de derecho de perjuicio referidas a las nulidades procesales cuando exista infracción que hubiere impedido el pleno ejercicio de garantías y derechos reconocidos en la Constitución, en los tratados internacionales y en las leyes.

Todo lo cual, además debe ser armonizado con el artículo 341 inc. final (en concordancia con el artículo 267 que establece la nulidad de ciertas diligencias) ${ }^{66}$, el cual alude al control sobre la prueba que se realiza en la audiencia de preparación del juicio oral. Esta norma dispone que el juez de garantía no debe admitir aquellas pruebas que

63 CAROCCA, Alex, op. cit. p. 308. El profesor ORTELLS RAMOS también señala casi los mismos derechos para el caso de España, op. cit. pp. 271 y 272

64 El futuro Código, contempla ciertas excepciones justificadas por su especialidad. Nos referimos a la investigación de hechos como hallazgo de cadáveres, identificación de difuntos, exhumaciones, lesiones, falsificaciones, entre otras, en que se impone la realización de peritajes. Art. 295 y ss.

65

En el concepto de BINDER, esto es una protección de primer nivel. Véase nota supra $n^{2} 46$

66

Este artículo dispone que el fiscal debe recabar la autorización del juez de garantía para aquellas diligencias que perturben o vulneren derechos fundamentales del imputado, salvo en casos urgentes situación en que queda pendiente la autorización. En caso que no solicite autorización para las diligencias indicadas esas diligencias son nulas. 
provinieren de actuaciones o diligencias que hubieren sido declaradas nulas y aquellas que hubieren sido obtenidas con inobservancia de las garantías fundamentales.

Otro camino o vía que permite la exclusión de la prueba ilícita debiera ser el recurso de casación y que debiera ser muy efectivo ${ }^{67}$, lo que sería aplicable al caso chileno según dispone el artículo 415 del Proyecto de C.P.P. que en su inc. $1^{\circ}$ consagra: "El recurso de casación se concede para los casos en que la sentencia se basare en la infracción de una disposición legal o constitucional".

Lo dicho hasta aquí hay que relacionarlo con la norma de rango constitucional contenida en el artículo $80 \mathrm{~A}$ de la C.P.R., inc. $3^{\circ}$, que consagra que el M.P. debe recabar autorización judicial para realizar aquellas actuaciones que priven, perturben 0 restrinjan los derechos constitucionales del imputado o de terceros ${ }^{68}$; de tal modo que si se realiza algunas de esas actuaciones sin autorización del juez de garantía, los medios de prueba que de ella provengan serían ilícitos y deberían ser excluidos del juicio o de la apreciación.

Por último basta decir que esta misma disposición tiene recepción a nivel legal en el artículo 93 del Proyecto de C.P.P. y en la LOC en el artículo 63 letra d (en este último caso como una prohibición).

Todas estas normas permitirán que la consagración de las disposiciones que contienen, como formas o mecanismo de recepción del concepto de prueba ilícita, operen efectivamente sirviendo de límite a la libertad de prueba y a la libre indagación de los hechos (manifestación del principio inquisitivo).

Por otra parte, el mecanismo de depuración de la prueba que se contiene en la etapa de preparación del juicio oral y que también debiera aplicarse en el juicio oral propiamente tal, servirá de límite configurador de la libre apreciación de la prueba, pues ésta como modo de apreciación, se refiere sólo a la prueba lícitamente obtenida ${ }^{69}$.

III.3. Valoración. Luego en lo atingente a la valoración libre de la prueba ya rendida en juicio, este sistema rechaza la determinación apriorística de valoración impuesta por la ley, pero contempla ciertos criterios de racionalidad tendientes a asegurar que la decisión que se tome, cuente con una fundamentación susceptible de ser analizada desde la perspectiva de la inteligencia. Para ello se recurre a criterios garantizadores de

67 BINDER, Alberto, op. cit. p. 37. Señala "Es mucho más útil y atinada la utilización de un sistema, aparentemente más laxo, pero mucho más efectivo. Se trata de regular con precisión la invalorabilidad de la información obtenida de un modo violatorio de las leyes del proceso. De este modo, se asocia necesariamente la nulidad de esa información con la decisión en la que debería ser utilizada y se puede lograr el mismo o mayor efecto de control, sin dar cabida a una utilización meramente dilatoria y sin afectar a la celeridad procesal. Por supuesto, todos estos temas están relacionados con los recursos procesales y, en especial, con el recurso de casación, ya que muchos de los supuestos de utilización de información viciada constituirían motivos absolutos o relativos de casación, y otros casos de casación formal, esconden, en realidad un ataque a la información de ciertos actos procesales conllevan"

68 Esto es lo que denomina BINDER, el segundo nivel de protección. Véase nota supra $n^{2} 46$.

Véase WALTER, Gerhard, op. cit. p. 315 y ss. 
racionalidad como las máximas de la experiencia, la reglas de la lógica, los conocimientos científicamente afianzados ${ }^{70}$.

Lo dicho es particularmente claro en el Proyecto de Código Procesal Penal chileno, que termina con las imposiciones y recomendaciones más o menos estrictas para cada medio de prueba destinadas al juez, hasta hoy, por el vigente Código de Procedimiento Penal ${ }^{71}$; contemplando, en cambio, los criterios ya referidos.

Sin duda que este es el punto más gravitante de cualquier sistema de prueba, en cuanto constituye el momento en que se determina el resultado de la actividad probatoria desplegada por las partes y consecuencialmente con ello el resultado de las pretensiones de las mismas, en tanto determina la decisión del conflicto.

Los criterios de libre valoración o de sana crítica según lo denominan algunos ${ }^{72}$. permitirían, como ya lo hemos dicho, revestir de racionalidad y precisión la actividad de juzgamiento. En esta línea, se puede decir, parafrasenado a Maier, que ello posibilita que la decisión se baste a sí misma.

La verdad es que esto tiene una doble connotación. Primero, la fundamentación - motivación de la resolución como forma de exteriorización de las razones y de las pruebas que se tuvieron en cuenta para tomar la decisión, y que constituye lo que se denomina exigencia externa; y en segundo lugar, que esa valoración se apoye sobre las leyes de la lógica y las máximas de la experiencia, abarcando todos y cada una de las conclusiones fácticas, y que constituye la exigencia interna de la actividad de apreciación $^{73}$.

70 Esto se justifica por la evidente fuerza que ha adquirido en el último siglo los métodos de indagación técnica y científica, de modo actualmente los jueces no se pueden sustraer a la aplicación de los conocimientos científicamente enunciados en principios y reglas, para la valoración de la prueba. Coincide con lo que algunos desde hace ya tiempo denominan prueba técnica o científica a la estadio de mayor desarrollo de la prueba, tomada de FERRI, por ejemplo, FREDAS, Pietro, op. cit., p. 24 y ss. y GORPHE, Francisco, La apreciación de las pruebas, Edit. E.J.E.A., Buenos Aires, Argentina, 1.955 p. 9 y ss y 60 y $5 s$.

En efecto, el futuro Código no contempla las imposiciones y recomendaciones para el juez que sí tiene el vigente, aunque se debe reconocer que de todas formas se reconoce cierta latitud al juez para valorar los medios de prueba. Nos referimos a las normas del artículo 459,460 y 464 sobre testigos; 472 sobre peritos; 474,475 y 476 sobre la inspección personal; 477 y 478 sobre prueba instrumental; 481,483 y 484 sobre la confesión.

72 Asi por ejemplo COUTURE, quien hace una división tripartita en la materia. Distingue el sistema de prueba legal y el sistema de libre convicción en los extremos; y como un sistema equidistante de éstos a la sana crítica. Diferencia la libre convicción de la sana crítica, pues cree que el primer sistema es aquel donde el juez aprecia con entera libertad, sin ninguna limitación o referencia a criterios de experiencia y de lógica. Afirma que el juez forma su convicción con la prueba de autos, fuera de la prueba de autos y aun contra la prueba de autos. En cambio la sana crítica, la conceptúa como aquel sistema en que el juez se forma la convicción utilizando las máximas de experiencia y apoyándose en las reglas de la lógica. Véase COUTURE, Eduardo, Fundamentos de Derecho Procesal Civil, Edit. Depalma, Reimpresión de Tercera edición, Buenos Aires, Argentina, 1990 y Estudios de Derecho Procesal Civil, Edit. Depalma, Buenos Aires, Argentina,1989.

73 Véase MAIER, Julio, op. cit. p.593. 
Todo lo cual, a la vez, admite y permite la natural forma de control de la libre apreciación, cual es, la casacionabilidad de la sentencia ${ }^{74}$. En efecto y según plantean Walter y Bofill (referidas principalmente a experiencias en el sistema Alemán) ${ }^{75}$. el tribunal de casación puede, a través del recurso de casación revisar la fundamentación por falta o errónea aplicación de las reglas de la lógica o de la experiencia.

Inclusive se puede, en la práctica, alcanzar aunque indirectamente, cuestiones de hecho, mediante el ataque de las conclusiones obtenidas por el juez de los hechos cuando el tribunal considere que las conclusiones del primero carecen de sustento o no son acertadas $^{76}$.

En España, según expone Asensio Mellado y Ortells Ramos ${ }^{77}$, también es factible la utilización del recurso de casación para la impugnación de una sentencia que transgreda las reglas de la apreciación de la prueba, conforme lo dispone el artículo 849 №2 de la Lecrim (Ley de Enjuiciamiento Criminal española). Por otra parte a nuestro juicio también es posible la impugnación de la apreciación de la prueba, mediante la aplicación de lo dispuesto en el artículo 851 que se refiere a causales de ley procesal, a juzgar por lo que explica Ortells Ramos ${ }^{78}$, aunque no lo dice explícitamente, se refiere al recurso de casación que procede por quebrantamiento de forma en la sentencia, específicamente lo referido a los vicios de motivación como la falta de claridad en los hechos probados, declaración no terminante de hechos probados y la contradicción entre los hechos declarados probados. Ello podría, a nuestro juicio, violentar la suficiente fundamentación o las reglas de la lógica

En lo que respecta a Chile, tenemos que el Proyecto de Código Procesal Penal contempla dos recursos, el de casación y el extraordinario, ambos de nulidad. El caso de Chile sería bajo este panorama un tanto distinto pues el control no vendría principalmente por medio del recurso de casación sino más bien por la utilización del recurso extraordinario, a juzgar por la propia redacción actual que al parecer destina a éste precisamente para controlar la correcta estimación de la prueba rendida en juicio, según se desprende del artículo 415.

No obstante, el recurso de casación podría ser igualmente aplicado para impugnar un fallo que violente la regla de la motivación de la sentencia, según se concluye de la aplicación del artículo 421 letra e, concordado con el artículo 382 letra c, que se refiere al contenido de la sentencia, específicamente a la mención de la valoración de la prueba en que se fundare conforme al artículo 201 que consagra la libre convicción.

\footnotetext{
74 Esto es una de las finalidades de la motivación y la utilización de la reglas de la lógica y de la experiencia, pues también se pueden mencionar como finalidades la de socialización de la actividad jurisdiccional y la de autocontrol del propio tribunal que falla. En sentido ASENSIO MELLADO, José María, op. cit. 
De modo que en Chile tendríamos en el futuro dos medios de control de la motivación y valoración de la prueba, mediante recursos.

III.4. Módulo de prueba. Lo expuesto también tiene otra arista y que no es más que el propio planteamiento de la finalidad de la libre valoración, cual es, la formación de una convicción con respecto a los hechos objeto de la prueba. En el futuro Código Procesal Penal chileno, se encuentra consagrado en el artículo 201 en los siguientes términos: "nadie podrá ser condenado por delito sino cuando el tribunal que lo juzgue hubiere adquirido la convicción de que realmente se ha cometido un hecho punible y que en él ha correspondido al acusado una participación culpable y penada por la ley". $Y$ aquí nos enfrentamos al arduo problema de determinar cuándo se debe considerar que los jueces se hallan convencidos legítimamente para pronunciar un fallo (obviamente condenatorio, pues para pronunciar la absolución se requiere nada más que la falta de convicción de la culpabilidad y no la convicción contraria, en homenaje a la presunción de inocencia). Ello nos lleva a plantearnos serios problemas sobre cuál es la finalidad del sistema procesal penal y el sustento de su legitimidad, es decir, cuándo se justifica y legitima la imposición de una sanción penal ¿cuando el tribunal tiene certeza sobre la existencia del hecho delictual, esto es, cuando el juzgador se convence de haber hallado la "verdad" ? o simplemente ¿cuando existe una probabilidad más o menos alta del acaecimiento del hecho?

Dicho de otro modo, los jueces sobre qué deben adquirir una convicción ¿Sobre la verdad o sobre la verosimilitud de los hechos objeto de prueba?. Esto es lo que se denomina el módulo o estándar de prueba; y su determinación es un arduo problema jurisprudencial y doctrinal.

En general, como ya lo hemos insinuado, existen dos grandes posiciones al respecto. Unos que creen que para poder dictar una sentencia condenatoria legítima se debe obtener por el juez la convicción a partir de haber llegado a la certeza o por lo menos a una verosimilitud rayana en certeza de la verdad de los hechos.

Estiman que si bien la verdad es una realidad a la que no siempre se puede acceder por medio del proceso, ella debe servir como ideal de aproximación.

Además lo que se exige es el convencimiento, es decir, el ánimo subjetivo del juez de tener la certeza de la ocurrencia de lo hechos, de modo que no es la verdad objetiva la que se debe alcanzar, sino más bien el convencimiento de que se ha hallado o constatado una versión de los hechos que se tiene por verdadera, habida cuenta de las limitaciones del conocimiento humano ${ }^{79}{ }_{-}^{80}$.

79 Lo dicho se puede ilustrar muy bien con la siguiente cita "Al tenerse algo por verdadero se relativiza el concepto absoluto de verdad que a primera vista se nos presenta. La misma ley respeta, pues, la insuficiencia de la capacidad humana de conocer lo verdadero. Lo que se ha de comprobar es lo que se tiene por verdadero. Quiere decir que a la ley no la anima de ningún modo el rigorismo que solo admite la verdad como base de la constatación de un hecho. Claro está que la verdad es un valor de aproximación, el norte que el juez tiene que afanarse por alcanzar". WALTER, Gerhard, op. cit., p. 171. Por su parte, de un modo análogo concluye GOR$\mathrm{PHE}$, quien exige la convicción de la máxima verosimilitud de manera que no admita otra posibilidad, salvo 
Otros, en cambio, plantean que ante la imposibilidad de llegar a la verdad por la propia impotencia del ser humano para ello, sólo es posible exigir al juez que falle de acuerdo a una cierta verosimilitud preponderante que se impone en la versión de los hechos.

Lo anterior, implica esencialmente una rebaja del módulo de prueba y al mismo tiempo una alteración en las reglas de la carga de la prueba ${ }^{81}$. En síntesis, consiste en una forma de facilitar la labor probatoria del Estado en su tarea de persecución, en tanto requiere probar menos ${ }^{82}$.

A nuestro juicio, por la propia redacción del artículo 201 del Proyecto de C.P.P., la nueva legislación optaría por el sistema de la convicción (que contiene certeza) de la verdad o de verosimilitud rayana en certeza, pues de la lectura de esta disposición queda clara su evidente connotación garantista de la presunción de inocencia, de modo que esta cedería sólo ante un grado de certeza sumo alcanzado por el órgano juzgador. Si la cosa fuere de otro modo. Si se aceptase como suficiente la verosimilitud para la condena, se estaría en la práctica, sentenciando por sospecha y esta situación sería inacepta-

por condiciones por completo extraordinarias y opuestas al curso normal de los hechos. Afirma que esto se logra esencialmente, mediante el uso de la lógica, de la razón y fundamentalmente de los medios de investigación técnicos y científicos. Op. cit, p. 485 y ss.

80 Una posición muy parecida sustenta también BRICHETTI, Giovanni, que afirma que existen dos tipos de evidencia. Una la metafísica que produce la certeza absoluta y otra que denomina práctica que es la única que puede obtenerse en el orden de las cosas humanas. La prueba judicial, dice, tiene por objeto no una verdad metafísica, sino una verdad contingente, de hecho, histórica, de modo que no posee un carácter absoluto ni inmutable, sino más bien relativo. Afirma incluso que lo que hoy puede parecer evidente, mañana puede no ser ya tal e incluso aparecer como verdad lo contrario. La evidencia en el Derecho Procesal Penal, Edit. Ejea, Buenos Aires, Argentina, 1.973 (traducción Santiago Sentis Melendo), pp. 5, 14 y 15. También FRAMARINO DEI MALATESTA, para quien la certeza no es más que un estado de la mente que consiste en la constatación racional de conformidad entre las ideas del sujeto y la verdad. $Y$ el convencimiento (judicial) es la certeza consentida y segura; se refiere al grado máximo de persuación a que llega el sujeto que la relación de conformidad entre la idea que se sustenta y la realidad. La certeza es la afirmación preliminar de la verdad, en el sentido que la noción ideológica se presenta como verdadera; el convencimiento es la posterior afirmación de que poseemos certeza, de que entendemos que ella es legítima, y que el espíritu no admite dudas en cuanto a esa verdad. El autor dice que si la certeza es la opinión de la verdad, el convencimiento es la opinión de la certeza como legítima. Reconoce eso si la limitación humana para lograr siempre la verdad de modo que declara la naturaleza subjetiva de la certeza y falible del convencimiento. Véase op. cit. tomo I, capítulo I, II, III.

81

Por supuesto que el concepto de carga de la prueba hay que entenderlo en un sentido diverso al del proceso civil, pues en él se comprende desde un punto de vista subjetivo, es decir, referido al perjuicio que le acarrea no probar a quien no cumple con esta carga, lo cual supone la existencia de partes parciales, interesadas como simples particulares en el proceso, cosa que no ocurre con el Estado representado por su órgano de persecución, sea el ministerio público u otro. En consecuncia creemos que se debe entender, la carga de la prueba en el proceso penal, en un sentido lógico y objetivo, es decir, como aquella consecuencia desfavorable que recae sobre la posición sustentada por el órgano de persecución estatal en caso que no pruebe el hecho punible y la participación culpable. Cfr. MICHELLI, Gian Antonio, La carga de la prueba. Edic. E.J.E.A., Buenos Aires, Argentina, 1.961 (Traducción por Sentis Melendo), pp. 265 a 276.

82 Véase WALTER, Gerhard, op. cit., cap. III. Este autor desarrolla en forma bastante completa la problemática de la fijación y, la rebaja del módulo de prueba que implica el sistema de verosimilitud. BRICEHTTI lo trata de un modo negativo dando razones de por qué se debería exigir en ciertos casos la evidencia como módulo de prueba aún para resoluciones provisionales, especialmente en el Derecho procesal Penal. 
ble pues violentaría a las claras la regla mínima del Estado de Derecho, que establece que la condena sólo puede apoyarse en la convicción de la culpabilidad del acusado.

Luego, el siguiente problema que se plantea, es el de determinar cuándo hay convicción. En la mayoría de los hechos que son objeto de constatación en un conflicto jurídico penal, presenta motivos a favor y en contra, afirmativos y negativos para confirmar su existencia. Sólo excepcionalmente nos encontraremos con hechos que pueden ser constatados en forma simple y directa por la existencia de motivos en único sentido. En consecuencia, el juzgador deberá recorrer un camino largo lleno de motivos contrapuesto para creer y no creer en los hechos que juzga. Duda se denomina el estado mental que revela la pugna interna de los motivos contrapuestos que produce una oscilación, como bien decía Mittermaier ${ }^{\beta 3}$, entre la afirmación y la negación.

Muchas veces ese estado mental de oscilación, de pugna no es superado por el juzgador o no es superado totalmente y los hechos no pasan de ser en esos casos dudosos o de probabilidad, respectivamente ${ }^{84}$. Estas deben ser las hipótesis de absolución.

Por el contrario, cuando el juzgador en la valoración acuciosa de la prueba rendida en juicio, es capaz de desechar los motivos que apoyan la versión negativa y acepta como verdaderos los motivos que apoyan la acusación, en ese momento adquiere convicción. Ahora bien esta convicción ¿no admite dudas de ningún tipo? En este punto seguimos lo expuesto en forma más o menos generalizada en el sentido de afirmar que es imposible en el contexto de la falibilidad humana descartar en términos absolutos la posibilidad contraria a lo que creemos como cierto. Eso vendría a ser una suerte de duda residual imposible de superar. Sin embargo de lo que se trata en la convicción judicial es que ella signifique una exclusión de las posibilidades concretas contrarias al hecho que se da por verdadero, es decir aquellas que tienen algún sustento en lo que se ha probado y no de las meras posibilidades abstractas. Seguimos aquí a cierta jurisprudencia y doctrina europea que ha razonado del mismo modo. Por ejemplo, la Corte Federal alemana fundamentó lo siguiente: "Para que haya convicción, es necesario, pero también suficiente que exista un grado de seguridad que según la experiencia de la vida, sea bastante para que ya no quepa oponerle dudas razonables". Y luego parece precisar qué se ha de entender por duda razonable, agregando: "La posibilidad meramente teórica o abstracta de que el acusado no haya sido el autor no puede impedir su condena. Puesto que una posibilidad de esa laya nunca puede excluirse enteramente debido a la falibilidad del conocimiento humano, toda averiguación judicial sería impo-

83 Este autor decia al respecto: "las oscilaciones del espíritu humano marcan, en efecto, la relación que existe entre las razones de creer y las de no creer; ahora bien, si los motivos que están a favor predominan de tal modo que destruyen cualquier verosimilitud de lo contrario, nosotros adquirimos certea, en cambio, si igualan los motivos contrarios nos encontarmos en estado de duda", op. cit., p. 62

La duda es aquel estado mental en que se hay equilibrio entre motivos positivos y negativos, la probabilidad, en cambio, es el estado de prevalencia de los motivos positivo. Véase CAFFERATA NORES, José, La prueba en el Proceso Penal, Edit. Depalma, $3^{\circ}$ edic., 1.998, Buenos Aires, Argentina, p. 11. También FRAMARARINO DEI MALATESTA, op, cit capitulo III. 
sible. Esta concepción de la esencia de la libre convicción judicial siempre fue sostenida en la jurisprudencia de los tribunales más altos ${ }^{105}{ }_{-86}$.

Walter, a su vez, resume lo que se ha entendido por sistema de convicción en doctrina: "Este modelo de convicción, sin embargo, no es distinto en cuanto a su esencia del preconizado por la jurisprudencia más reciente, y en el que la orientación por algún tipo de verosimilitud es criticada solo en cuanto se pretendiera prescindir de formarse una convicción propia... El "modelo de la convicción de la verdad" -llamémoslo así- exige del juez que esté personalmente convencido de la verdad de un hecho. Tiene que tener en cuenta, empero, que el conocimiento absoluto de la verdad está vedado al espíritu del hombre. Por eso no debe permitir que lo desconcierten o turben dudas que no son más que el fruto, precisamente, de esa limitación del conocimiento humano. Esas dudas (abstractas, teóricas, etc.) no deben ser atendidas" ${ }^{87}{ }_{-}^{88}{ }_{-}^{89}$.

Si ya sabemos en qué consiste la convicción, la pregunta siguiente es determinar si es posible concebir alguna forma de legitimar esa actividad. Sobre el particular estimamos que es fundamental que la convicción sea fruto de un proceso cognitivo y volitivo exento de arbitrariedad, del capricho del juzgador. Esto es justamente lo que le otorga el título de legitimidad.

Para ello debemos contar, una vez más con un criterio que permita la operatividad de esta idea. La convicción que ha de formarse el juzgador debe tener en cuenta no sólo su propia persuación sino también un carácter racional objetivable de esa convicción que se comprueba al contrastarla con ciertos estándares o criterios prefijados, así por ejemplo se ha pronunciado Peters: "si basta la certidumbre del juez...o si, por el contrario, no tendría que estar objetivamente asegurada la sentencia basada en certeza en cuanto otros jueces tuvieran que estar en condiciones de repetirla. La solución correcta es esta última. Sólo así se impediría que el individuo quede librado al accidente o a la casualidad de la subjetividad del juez. Por tanto, en cuanto a la libre apreciación de

Fallo de la Corte federal alemana de 1.952 citado por WALTER, Gerhard, op. cit. p. 112.

86 Una posición análoga encontramos en el Italiano BRICHETTI, que lo expresa en los términos que siguen: "La certeza moral, observaba Gioberti, desde el punto de vista objetivo es solamente una gran verosimilitud, una fuerte y rígida probabilidad, pero es una plena certeza en relación a nuestra naturaleza... De otro lado no debe olvidarse que en el campo del derecho no es la posibilidad de una duda abstracta, metafísica, no es el escepticismo, el que regula el movimiento jurídico: el criterio de la certeza moral puede guiar al magistrado a buscar la verdad del modo seguro y tranquilizador, hasta el punto de que su ánimo desaparezca toda sombra de duda, tanto más si dicho criterio va acompañado por el de la evidencia...". Op. cit. p. 15

87 Ibid., pp. 150 y 151

88 Esto de la duda razonable también es enunciado por Framarino (aunque no logra conceptualizarlo y darle un contenido concreto). Se refiere a ello en diversas ocasiones a lo largo de su obra sobre la prueba. En síntesis estima que la convicción en general es el resultado de un proceso complejo en que los motivos divergentes son excluidos, rechazados, porque no merecen ser racionalmente considerados. FRAMARINO DEI MALATESTA. op. cit. p. 64

89 Luego enuncia a propósito de las presunciones el único precepto básico sobre la convicción: "Para nosotros solo hay un precepto que es único, para toda especie de prueba, y es el siguiente: para la sentencia condenatoria sea juridicamente válida, el convencimiento que surge de las pruebas no debe tener en su contra ninguna duda racional". Ibid., p. 271. 
la prueba están sometidos al reexamen en casación no solamente el mismo proceso de apreciación, sino también el resultado... Por cierto que ese reexamen tiene que limitarse a conclusiones especialmente llamativas" ${ }^{\prime \prime 0}$.

A su vez Stree señala: "Aún cuando la libre apreciación de la prueba por el juez constituye un trabajo personal, el juez tiene no obstante que asumir al realizarlo una actitud cabal y conforme a su deber. Tiene que juzgar lo más objetivamente que sea posible. El deber de objetividad tiene que servirle de freno para no dejarse arrastrar subjetivamente a adoptar una convicción determinada a fin de lograr a todo trance una condena. Ese deber, por el contrario, que procure formarse con el auxilio de la voz de la razón, un criterio que...todo ser humano que sea uno de ellos y disponga de los conocimientos de causa necesarios pueda repetir mentalmente" ${ }^{11}$.

Como se ve el concepto que hay detrás es que el convencimiento del juez debe ser una garantía de racionalidad y para que esto ocurra se requiere que la convicción que se forme sea susceptible de repetición intelectual por un tercero ${ }^{92}$, lo que viene a ser la prueba de blancura de racionalidad de la convicción y lo que insufla legitimidad a la decisión ${ }^{93}$. Por lo demás lo anterior vendría a ser una consecuencia del carácter social del convencimiento judicial, que tan bien explicaba un clásico ${ }^{94}$, que según él se encarna en el concepto de cualquier otro ciudadano.

Sin embargo, la exigencia de repetibilidad por un tercero, independiente de quien sea esta figura de referencia: un juez medio o varios jueces, un hombre medio, etc; no deja de ser un concepto que carece de contenido, es meramente formal, por lo que a nuestro juicio, para darles un contenido real, es menester entenderlos como ciertas construcciones prácticas que la dogmática ha denominado estándar o concepto

90 PETERS, citado por WALTER, Gerhard, op cit. p. 153.

91 STREE, citado por WALTER, Gerhard, op, cit, p. 154

92 El concepto de repetibilidad por un tercero puede tener por referente a un "juez", "juez medio" o a "una persona con los conocimientos necesarios".

93

En este sentido hace especial énfasis BINDER, para quien el sistema de control por terceros es esencialmente un modelo que se encuentra en el plano de la legitimidad de la construcción del relato que debe elaborar el juez en su decisión. Op. cit., nota a pie de página, pp. 43 y 44

94 Este autor dice al respecto: "El juez no puede, aunque crea legítimo su propio convencimiento, condenar legítimamente sino cuando crea que los hechos y las pruebas que han sido sometidos a su examen, si se propusieran al juicio desinteresado de cualquier otro ciudadano, darían por resultado, también en este último, esa misma certeza que han producido en su espíritu"

"Como debemos siempre aspirar a que el convencimiento judicial tenga la calidad de social, y como en orden a la culpabilidad del acusado también debe existir indefectiblemente ese requisito, síguese de ello que el juez no debe nunca fundar sus persuaciones en lo que él conoce en su condición de individuo particular. En cuanto a a su conciencia nada más cierto que lo percibido directamente, pero no es lo mismo en cuanto a la conciencia social. Si el juez ha tenido concoimiento privado del hecho criminoso, o de los hechos que prueban inocencia debe hacer de lado su condición y presentarse como testigo..."

"En esa condición social, que es una especie de objetivación de la certeza, radica la mejor determinación del convencimiento judicial, determinación que le impide a este conventirse, de modo más o menos hipócrita, en arbitrariedad del juez". FRAMARINO DEI MALATESTA, op. cit., tomo I, pp. 57 y 121 y sS. 
jurídico, y en donde parece natural admitir la intervención decisiva de la doctrina y la jurisprudencia en la labor de determinación de los contornos del mismo ${ }^{95}$.

La determinación del significado de estos conceptos en cada momento es una labor de la jurisprudencia y la doctrina, por eso se afirma por una sentencia que si bien las reglas de la sana crítica es una regla permanente en los principios de la lógica, es contingente y variable en cuanto a la experiencia del tiempo y lugar ${ }^{96}$. Couture asegura que el concepto de estándar supone una remisión al magistrado para que apreciese en el momento del fallo. Sin duda, agrega, constituye un problema de grado en donde la estimativa jurídica juega un papel preponderante ${ }^{97}$.

De Paula ${ }^{98}$ agrega al respecto que "La ley, con la institución de la sana crítica, como control del arbitrario de los tribunales en la apreciación libre de la prueba testimonial, ha creado lo que la doctrina conoce con la denominación de un standard jurídico; o un concepto límite saturado de contenido, cuyo desarrollo queda a cargo de la doctrina científica".

Ahora bien, la idea de control por tercero supone la presencia de un concepto referente, que, como se ha dicho, puede ser el de juez prudente o jueces medios o el ciudadano medio, pero que para poder determinar su verdadero significado es menester recurrir a ciertos patrones o comportamiento sociales de conducta válidos, previamente establecidos dentro de un contexto. Aquí se halla otra característica del carácter social del convencimiento. Tal vez la determinación de esto sea un desafio importante para el futuro sistema de enjuiciamiento criminal, el desarrollo de una jurisprudencia más dinámica en la fijación de conceptos o estándares.

Por último cabe destacar, que el control por terceros o la exigencia de repetibilidad, tiene especial relevancia en torno a la revisibilidad ${ }^{99}$ y sus alcances. Los problemas

95 En efecto, así se las ha concebido desde siempre. Es clásico por ejemplo el caso del Derecho Romano del cual heredamos importantes estándares que fueron determinados en su significado concreto por la labor progresiva de la jurisprudencia.

Por ejemplo Couture dice al respecto: "Por tal se entiende, según hemos tenido otra oportunidad de destacar. una línea de conducta general susceptible de abarcar numerosas situaciones, representativas de cierta medida de comportamiento social" y luego agrega "El derecho romano nos ha legado numerosos standards jurídicos tales como los conceptos de buena fe, la insolvencia notoria, la incapacidad notoria, etc" y en seguida agrega algunos estrictamente procesales: "El prudente arbitrio del juez, la malicia temeraria al litigar, los conceptos de embargo bastante cubrir la deuda, de fianza suficiente, etc. COUTURE, Eduardo. Estudios de Derecho Procesal Civil, II, pp. 224 y ss.

96 Esto es lo que afirma en síntesis un fallo del Tribunal de Apelación de Montevideo, 1.955, citado por SENTIS MELENDO, Santiago, La Prueba, , Edic. E.J.E. A., Buenos Aires, Argentina, 1.979, pie de página 276. En el caso del Proyecto de Código Procesal Penal chileno, se acoge esto, a nuestro juicio, en la reglamentación de la casación per saltum, en el artículo 418 , que la consagra para el caso de que lo solicitado implique un cambio de los criterios jurisprudenciales vigentes.

97 COUTURE, Eduardo, op. cit. pp. 225 y 226

98 DE PAULA PÉREZ, Alfonso, La prueba de testigos, citado por SENTIS MELENDO, op. cit. p. 277.

99 En el caso del Proyecto de C.P.P. no tengo claro si con la redacción de las normas de la casación se puedan entender comprendidas estos tópicos, tal vez en esta materia es más apropiada la redacción del recurso extraordinario, permitiendo una revisión más cabal en el caso de una sentencia condenatoria 
que aquí se plantean tienen que ver con qué se controla, es decir, si la repetibilidad alcanza solamente a la violación o mala aplicación formal de las leyes de razonamiento - las reglas de la experiencia o los conocimientos científicamente afianzados o, si derechamente es suceptible de ser revisado el propio convencimiento y su formación. Y si de ese modo, la revisibilidad permite entrar en la modificación de los hechos ${ }^{100}$. También aquí habrá otro problema que se tendrá que definir una vez que se ponga en marcha en el nuevo sistema.

100 Véase CAROCCA, Alex, Recursos en el Nuevo Proceso Penal, p.18 (artículo sin publicar). Este autor señala que el recurso de casación tal como lo contempla el Proyecto de Código Procesal Penal, admite entrar en los hechos a propósito de la valoración de la prueba y también mediante la aplicación de las garantías del debido proceso, especialmente la presunción de inocencia. 